\title{
State Use Provisions for Patent Law, and Expropriations: Some Comparative Law Guidelines for South Africa during the Covid-19 Crisis and Beyond
}

\section{P.E.R}

Pioneer in peer-reviewed, open access online law publications

Author

Mikhalien du Bois

Affiliation

University of South Africa

Email

dboism@unisa.ac.za

Date Submission

11 April 2020

Date Revised

3 September 2020

Date Accepted

3 September 2020

Date published

15 September 2020

\section{Editor Prof C Rautenbach}

How to cite this article

Du Bois M "State Use Provisions for Patent Law, and Expropriations: Some Comparative Law Guidelines for South Africa during the Covid19 Crisis and Beyond" PER / PELJ 2020(23) - DOI

http://dx.doi.org/10.17159/17273781/2020/v23i0a8150

\section{Copyright}

DOI

http://dx.doi.org/10.17159/1727-

3781/2020/v23i0a8150

\section{Abstract}

This article views section 4 of the Patents Act 57 of 1978 against section 25 of the Constitution of the Republic of South Africa, 1996 and Article 31 of the Agreement on Trade-Related Aspects of Intellectual Property Rights of 1994 (hereafter TRIPS). The purpose is to find a suitable framework for the state/government use/utilisation of patented products or processes for public purposes. A comparison is done with the Crown use provisions in United Kingdom, Australian and Canadian law to find a suitable approach to questions relating to remuneration for state use, the prior negotiations requirement set by Article 31 of TRIPS, and the public purposes and exclusive patent rights that would be included under state use. The COVID-19 international pandemic has caused a state of national disaster in South Africa, which is exactly the kind of situation of extreme urgency envisioned by the exception in Article 31 of TRIPS, which permits the state use of patents without requiring prior negotiations with the patent owner. In the battle against COVID-19 and its concomitant fallout, the South African government (and authorised private parties) would be permitted to utilise patent rights without explicit authorisation from the patent owner and without prior negotiations, but subject to the payment of reasonable remuneration by the government and other terms and conditions as agreed upon or as determined by a court. This may include making (manufacturing), using, exercising, and importing patented products (for example, personal protective equipment, pharmaceuticals, ventilators and diagnostic tests) deemed necessary in the fight against COVID-19. Foreign jurisdictions considered in this article indicate that section 4 of the Patents Act 57 of 1978 may certainly benefit from an update to provide detailed guidance on the state use of patented products or processes for public purposes. In the interest of a timeous offensive against the COVID-19 virus, the patent provisions need a speedy update to allow state use compliant with TRIPS and the Constitution of the Republic of South Africa, 1996.

\section{Keywords}

Constitutional property law; intellectual property law; patent law; state use of patents; government use of patents; Crown use of patents; patent utilisation; public use; TRIPS Article 31; TRIPS exceptions; expropriations; takings; national disaster; national emergency; COVID-19. 


\section{Introduction}

Statutory monopoly rights granted as patents protect qualifying inventions. The essence of these rights is that patentees may prevent others from exploiting their inventions for a fixed term from the date of the application for a patent, 20 years ${ }^{1}$ in South African law. In return for this monopoly right, the patentee must fully disclose the invention so that others may freely use it after the expiry of the term, once it falls in the public domain. ${ }^{2}$ In order to be patentable, an invention must be novel, ${ }^{3}$ inventive, ${ }^{4}$ and capable of application in trade, industry or agriculture. ${ }^{5}$ Once the registrar grants a patent, the patentee has the right to exclude other persons from making, using, exercising, disposing of, offering to dispose of, or importing the invention into South Africa, for the patentee to "have and enjoy the whole profit and advantage accruing by reason of the invention." ${ }^{6}$ Doing any of these acts reserved exclusively for the patentee without authorisation amounts to infringement. ${ }^{7}$

A patent is valuable to society only when effectively utilised, and utilisation may occur through assignment and licensing. This links to the human flourishing theory of property, which postulates that property is not only about rights, but also about obligations, including social obligations. ${ }^{8}$ This is

Mikhalien du Bois. LLB LLD (US). Associate Professor: Department of Mercantile Law, Unisa, South Africa. E-mail: dboism@unisa.ac.za, ORCiD: 0000-0001-91718760. This article was first presented as a paper at the Association for Law, Property, and Society's 10th Annual Meeting in May 2019 at Syracuse University, Syracuse, New York. The Unisa School of Law Research and Innovation Fund made this visit to Syracuse University possible financially. Thank you to the participants for their comments. I had an additional opportunity to elicit comments when the article was presented at the South African Association of Intellectual Property Law and Information Technology Law Teachers and Researchers Conference in July 2019 at the University of Cape Town. Thank you especially to Richard M. Shay, who read numerous drafts and discussed ideas on the topic.

$1 \quad$ Section 46 of the Patents Act 57 of 1978.

$2 \quad$ Grant "Patents" 239; Van der Merwe "Law of Patents" 359; Burrell Burrells South African Patent and Design Law paras [1.3], [3.2].

$3 \quad$ Sections 25(5)-(9) and 26 of the Patents Act 57 of 1978.

$4 \quad$ Section 25(10) of the Patents Act 57 of 1978; Roman Roller CC v Speedmark Holdings (Pty) Ltd 19961 SA 405 (SCA); Ensign-Bickford (South Africa) (Pty) Ltd v AECI Explosives and Chemicals Ltd 19991 SA 70 (SCA); Schlumberger-Logelco Inc v Coflexip SA 20003 SA 861 (SCA); Ausplow (Pty) Ltd v Northpark Trading 3 (Pty) Ltd 20114 All SA 221 (SCA).

5 Section 25(1) of the Patents Act 57 of 1978.

$6 \quad$ Section 45(1) of the Patents Act 57 of 1978.

$7 \quad$ Section 45(1) of the Patents Act 57 of 1978; Grant "Patents" 273; Van der Merwe "Law of Patents" 420.

$8 \quad$ Alexander 2013 https://scholarship.law.cornell.edu/facpub/653/ 10: "Ownership is not about rights only; it is equally about obligations [and] the soundest normative foundation of those obligations is human flourishing." 
particularly applicable to patents, since the entire reason for the protection of patent rights lies in the quid pro quo theory. ${ }^{9} \mathrm{~A}$ patent owner receives monopoly rights for a limited time under the understanding that the public must benefit both during the term of the patent (via utilisation or licensing to facilitate access to patented products) and once the term has expired (via information falling into the public domain).

The operation of law and assignment may transfer the ownership of patents. Some or all rights may transfer on assignment, and a patent may be attached or subject to hypothecation. ${ }^{10}$ Voluntary licences facilitate patent owners to permit third parties to exercise all or some exclusive patent rights. For example, a patentee may license a pharmaceutical company to exclusively manufacture and sell its patented medicine in South Africa for five years, subject to the payment of a yearly licence fee, with or without royalties. ${ }^{11}$

The Patents Act 57 of 1978 (hereafter the Patents Act or South African Patents Act, when contrasting it with the Acts of other jurisdictions) also provides for compulsory licences for dependent patents, ${ }^{12}$ and the abuse of patent rights. ${ }^{13}$ The first applies where a patentee cannot utilise a patent without infringing a prior patent, a situation which could stifle innovation. The latter generally applies where an invention is inadequately utilised in South Africa, which is detrimental to the public. For example, where a patent holder fails to meet the demand for a patented article or its price is too high relative to that in other countries. Both forms of compulsory licences make technological innovations available in the public interest, and the commissioner of patents may determine the licence conditions, including the remuneration due by the licensee. While compulsory licensing provisions also constitute a TRIPS flexibility that is available to the government to facilitate access to patented products and processes, the focus of this article falls on the state or government use provisions contained in the Patents Act. ${ }^{14}$

See Letraset Ltd v Helios Ltd 19723 SA 245 (A) 249; Premier Hangers CC v Polyoak (Pty) Ltd 19971 SA 416 (A) 424I; Merck Sharp Dohme Group v Cipla Agrimed (Pty) Ltd 2015 BIP 101 (SCA) para [2]; Alberts 2007 De Rebus 45; Grant "Patents" 239; Van der Merwe "Law of Patents" 359; Burrell Burrells South African Patent and Design Law para [1.1]; Du Bois 2018 PELJ 1-38.

Section 59 and 60 of the Patents Act 57 of 1978.

Biagio "Commercial Considerations" 361-362, 366-372.

Section 55 of the Patents Act 57 of 1978.

Section 56 of the Patents Act 57 of 1978.

This article does not aim to provide a comprehensive overview of all patent law mechanisms that are available to facilitate access to essential pharmaceuticals, or 
Somewhat peculiar to the patent regime - as opposed to other categories of property, ${ }^{15}$ but not peculiar to South African law in particular - is the fact that provisions for the utilisation, acquisition and assignment of inventions or patents by the state are made in the governing legislation, the Patents Act. These encapsulate three distinct categories of use for state purposes or "government use". ${ }^{16}$

In the United Kingdom, Australia and Canada, comparable provisions are termed Crown use provisions. Broadly, the state may utilise or acquire any invention or patent. This may entail either a negotiated acquisition or a unilateral divestment, depending on the circumstances. The provisions provide guidance where a negotiated acquisition fails and an expropriation (a taking or acquisition) of property or property rights happens. In the case of acquisition, ownership and all beneficial uses are taken over. With state utilisation, not all patent rights are necessarily implicated, and it may be only temporary. Patent rights granted to qualifying inventions in terms of the South African Patents Act are included under the constitutional property concept $^{17}$ and as such are protected against arbitrary deprivations and

an analysis of all available Agreement on Trade-Related Aspects of Intellectual Property Rights (1994) (TRIPS) flexibilities. Its focus falls exclusively on the state (or government) use and acquisition provisions that allow only the Government to utilise or acquire patents for public purposes, especially where these need to be accessed quickly in order for the Government to provide services to the public. This article also does not focus on compulsory licensing, which is another TRIPS flexibility that may also be utilised by the Government. See Du Bois 2018 SAIPLJ 80-90, for an analysis of South African compulsory licensing provisions, the doctrine of the exhaustion of rights in patent law, Articles 30bis and 31 of TRIPS, and other methods to facilitate access to essential pharmaceuticals. For further reading on the application of TRIPS flexibilities, see Park, Prabhala and Berger Using Law to Accelerate Treatment Access, particularly at 55-72 (paras 2.5-2.6); Vawda and Shozi Eighteen Years after Doha, particularly 27-31. On compulsory licensing, see Vawda 2019 SAIPLJ, particularly at 197-198 on the strengthened role that compulsory licensing should play in access to pharmaceuticals; Vawda Compulsory Licensing Jurisprudence 19. Excepting s 46 of the Designs Act 195 of 1993, permitting secrecy of designs in the national interest, subject to reasonable compensation by the Minister to the design proprietor, as may be agreed upon, determined by arbitration, or by a court. The Patents Act 57 of 1978, under s 4 and Chapter XIV (Acquisition of rights to inventions and patents by the State) encompassing state acquisitions (s 78) and assignments (s 79) of patents. In general, in South African, United Kingdom, Australian and Canadian law, the term "remuneration" is used to refer to that which would be due to the patent holder for state/government/Crown utilisation of patents, while "compensation" is used to refer to the payment received by a patent holder for state/government/Crown acquisitions of patents or assignments of patents to the State. "Compensation" generally caters for a broader range of affected interests than "remuneration", which is often defined as simply what a willing licensee would pay for the utilisation of a patent.

17 Section 25 of the Constitution of the Republic of South Africa, 1996 (the Constitution). A patent is vested and hence protectable in terms of the constitutional property clause once it complies with the requirements and is registered, but since 
uncompensated expropriations. ${ }^{18}$ Hence, the state use provisions in the Patents Act may be tested against section 25(1), (2) and (3) of the Constitution of the Republic of South Africa, 1996 (hereafter the Constitution).

No South African court cases provide clarity on the precise meaning and intended purpose of the state use provisions, therefore this article undertakes a comparative and constitutional study, with a focus on United Kingdom, Australian, and Canadian law, to provide interpretational clarity. The article outlines the South African state use (utilisation, acquisition and assignment) provisions and puts them into perspective as far as constitutional property law is concerned. It also illuminates some select issues from comparative jurisdictions, in order to provide some clarity and guidance for South African law, especially in the light of the intentions of the Intellectual Property Policy Phase 1 2018, to update the state (government) use provisions. ${ }^{19}$

Likewise, the other jurisdictions dealt with in more detail below have a paucity of case law. It is likely that these states employ Crown use provisions as a bargaining chip. Once the state threatens to invoke state use provisions, patent owners are more likely to agree to voluntary licensing or assignment. Hence the lack of a body of case law.

the priority date of a patent is the date of application and there are already property interests at that stage, it is viewed as conditionally protected in the period between application and registration. If the registrar grants a patent, the interests become vested rights and if not, the interests lapse and are no longer protectable as property interests. See Du Bois 2018 SAIPLJ 67-91; Du Bois and Shay "Regulation at the Edge of the Property Concept" 419-446 on intangible property interests that South African courts have accepted as constitutional property. For arguments pro the inclusion of intellectual property rights under the constitutional property clause (s 25 of the Constitution) see Van der Walt Constitutional Property Law 143-150; Du Bois 2012 SA Merc LJ 177-193; Van der Walt and Shay 2014 PELJ 52; Burrell Burrells South African Patent and Design Law para [1.15].

18 Section 12(3) of the Draft Expropriation Bill, 2019 (GN 1409 in GG 42127 of 21 December 2018) proposes reforms to $s 25$ of the Constitution to introduce nil compensation for expropriation. In its current form, these changes are aimed only at immovable property in the context of land reform and are hence unlikely to affect intellectual property such as patents, although the final amendment may change this position. See Viljoen 2020 TSAR 37-40; Hoops 2019 SALJ 261 on the implications of this proposed amendment.

19 Intellectual Property Policy of the Republic of South Africa Phase 12018 (Gen N 518 in GG 41870 of 31 August 2018) 28-29 (para 7.1.9.1 Government use). 


\title{
2 A constitutional approach to state use provisions in the South African Patents Act
}

\subsection{State utilisation of patents via section 4 of the Patents Act}

The state use provisions in the Patents Act have not received much attention in academic scholarship. ${ }^{20}$ Section 4 of the Patents Act determines:

\begin{abstract}
A patent shall in all respects have the like effect against the State as it has against a person: Provided that a Minister of State may use an invention for public purposes on such conditions as may be agreed upon with the patentee, or in default of agreement on such conditions as are determined by the commissioner on application by or on behalf of such Minister and after hearing the patentee. ${ }^{21}$
\end{abstract}

In this case, the state may utilise a patent for public purposes by making, using, exercising, or importing the invention, for example. Whether state use should also include disposing of or offering to dispose of the invention is more contentious. Broadly speaking, state use provides a defence against patent infringement that the state or an authorised person may use, subject to remuneration. A succinct description highlights the differences between compulsory licences and state use (or government use): They are "two distinct policy tools: 'compulsory licences', as issued by courts, and 'government use' as issued by the state."22 The vague wording of section 4 raises many questions: Is it an acquisition that might be an expropriation, or does it entail only temporary use without taking over all beneficial uses? The rights in the bundle of exclusive rights connected to a patent entail the prevention of unauthorised use, and if the state exercises all the rights, what is left? How long the state uses the patent for is crucial, since a patent term is only twenty years, and for pharmaceuticals the term is even shorter once all regulatory approvals are complete. Which kind of conditions of exploitation might be appropriate for the commissioner of patents to determine? They have to include some form of remuneration, but how

20 Ramsden Guide to Intellectual Property Law provides little elucidation on state use provisions: 239 on s 4, 342 on ss 78 and 79, 343-344 on s 80. Park, Prabhala and Berger Using Law to Accelerate Treatment Access 57-61 (para 2.6) considers the provisions in greater detail.

21 Section 4 of the Patents Act 57 of 1978. The list of definitions in s 2 of the Patents Act 57 of 1978 defines "Minister" as the Minister of Economic Affairs and Technology (in 2009 this portfolio was split into Economic Development and Trade and Industry, and since 2019 it is once again combined under the portfolio of the Minister of Trade and Industry). 
should that be determined $?^{23}$ Must the Minister approve use before or after use commences? When/are prior negotiations with the patent holder mandatory ${ }^{24}$ When and for which purposes would the state be justified in invoking state use provisions under section 4 ?

Although section 4 of the Patents Act provides for a negotiated acquisition of patent use where possible, ${ }^{25}$ the wording of the article also provides guidance where such a negotiated acquisition fails and a unilateral divestment and as such a possible expropriation takes place. ${ }^{26}$ The section requires that the Minister should have attempted to negotiate with the patentee, but failing that, the commissioner would determine the conditions for use. However, the section does not explicitly state whether conditions must be determined before the exploitation commences. The state use provisions in section 4 of the Patents Act constitute the authorising legislation for a legitimate expropriation as required by section 25(2), and the state can therefore expropriate a patent for a public purpose or in the public interest. State actions taken in terms of these provisions may be tested against section 25(1), (2) and (3) of the Constitution.

In the light of section 25(2) and (3) of the Constitution, the conditions so determined by the commissioner of patents would have to include payment of just and equitable compensation in line with the factors provided in subsection (3). These are (a) the current use of the property, (b) the history of the acquisition and use of the property, (c) the market value of the property, (d) the extent of direct state investment and subsidy in the acquisition and beneficial capital investment of the property, and (e) the purpose of the expropriation. Subsection 4(b) states explicitly that property is not limited to land, so the expropriation provisions in section 25 are applicable to intellectual property as well as tangible property.

23 Park, Prabhala and Berger Using Law to Accelerate Treatment Access 57 (para 2.6): "[T]he provisions for government use are inadequate; and the guidelines for determining adequate remuneration with respect to both compulsory licenses and government use are vague."

24 In the US a patentee does not even have to be informed of government use, and would merely be entitled to compensation based on eminent domain after the fact, as provided by the Tucker Act 28 USC §1498(a).

Burrell Burrells South African Patent and Design Law paras [3.19]-[3.22] defines public use in s 4 of the Patents Act 57 of 1978 as "putting the invention into practice for public purposes." This would include disposing of or offering to dispose of the invention under the acts that the state would be permitted to do in terms of this section [para 3.20]. 


\subsection{Other provisions in the Patents Act providing State powers relating to patents}

Chapter 14 of the Patents Act, "Acquisition of rights to patents and inventions by the State", includes provisions on acquisition, ${ }^{27}$ the assignment of patents relating to armaments, ${ }^{28}$ and the secrecy of patents in the national interest. ${ }^{29}$ Section 78 of the Patents Act on acquisition provides that "the Minister may, on behalf of the State, acquire, on such terms and conditions as may be agreed upon, any invention or patent." It stipulates who may acquire patents and inventions on behalf of the state, namely the Minister of Economic Affairs and Technology, ${ }^{30}$ as outlined in the definitions of the Patents Act. If the parties do not agree on the conditions,$^{31}$ the provisions further provide for arbitration or for the commissioner of patents to determine the relevant conditions. The state or Minister cannot simply impose conditions; these need to be determined with reference to constitutional principles. Where the compensation is inadequate or the terms and conditions unfair, that could amount to arbitrary deprivation or an unconstitutional expropriation, depending on the particular facts. Where the parties reach no agreement it is likely that a High Court judge sitting as the commissioner of patents would have to ensure that the terms, including the remuneration, were fair and in line with constitutional principles. The Patents Act (or regulations) could incorporate clearer guidelines and more precisely defined terms for state or government use in terms of section 4, as is the case with acquisitions. No South African court cases elucidate the processes facilitating either state use or state acquisitions.

Section 79 , on the assignment of certain patents to the state, stipulates that

[t]he proprietor of an invention relating to any armaments ... shall, if called upon to do so by the Minister of Defence, assign the invention ... to that Minister on behalf of the State. ... (8) [subject to] reasonable compensation as may be agreed upon or as may, in default of agreement, be determined by arbitration or, if the parties so agree, by the commissioner. ${ }^{32}$

Section 78 of the Patents Act 57 of 1978.

Section 79 of the Patents Act 57 of 1978.

Section 80 of the Patents Act 57 of 1978.

Now the Minister of Trade and Industry.

Burrell Burrells South African Patent and Design Law para [3.21]: s 78 authorises only a negotiated acquisition and not a unilateral divestment. However, this cannot be the provision's purpose since $s 4$ already lets the state effect a negotiated acquisition, like any private party. 
The Minister can also direct the secrecy of the invention and the manner of its performance, in line with the provisions of section 80 , subject to compensation to the patentee.

Under section 79 the patentee cannot refuse to assign the invention or patent to the state - the wording mandates that the patentee shall assign. Parties may negotiate on the compensation, but failing agreement, arbitration or the commissioner of patents would determine it. The provision explicitly mandates compensation, because the state acquires and necessarily takes over all beneficial interests as well as the title of the property in the patent or invention, and uncompensated acquisition would entail an unconstitutional, uncompensated expropriation. Compensation needs to be determined in line with the guidelines set out in section 25(3) of the Constitution. Especially since the Patent legislation is pre-constitutional, the scope of the powers of the Minister and the way in which compensation is determined need re-evaluation during any amendment to the legislation.

The South African state use provisions were included in the old Patents $A c t,{ }^{33}$ and termed "restrictions in favour of the State [and] exceptional sacrifices forced on patentees in favour of public interest, [resting] unequally on members of the public."34 This is still applicable to the current Patents Act, since it always concerns a specific category of patents (related to national defence) or a specific patent owner (the use of a specific patent for a public purpose). This is very close to the justifications underlying compensation for expropriation, which requires a constitutional property analysis during the application of the state use provisions to determine compliance with the Constitution.

\subsection{Possible improvements to section 4 of the Patents Act as suggested in the Intellectual Property Policy Phase 12018}

South Africa's Intellectual Property Policy Phase $12018^{35}$ mentions the state/government use of patents, citing section 4 of the Patents Act. ${ }^{36}$ The

33 The Patents Act 37 of 1952: ss 58, 59, 60 and 61 on the use, acquisition, assignment and compensation, respectively. Gerntholtz Principles of South African Patent Law 213-217: the German Federal Government also can use an invention in the interest of public welfare or for the security of the state, subject to reasonable compensation from the state. Intellectual Property Policy of the Republic of South Africa Phase 12018 28-29 para 7.1.9.1.

36 The previous draft of the policy explicitly included that the state use sections should be utilised to promote access to public healthcare. See the Draft Intellectual Property Policy of the Republic of South Africa Phase 12017 (Gen N 636 in GG 41064 of 25 August 2017) 24 (7.1.9.1 Government use): "[The] state is obliged to take reasonable 
policy refers to the Agreement on Trade-Related Aspects of Intellectual Property Rights ${ }^{37}$ (hereafter TRIPS) and suggests updating the government use provisions to make full use of the exception contained in Article 31(b) of TRIPS. It determines that prior negotiations are not required "in the case of a national emergency or other circumstances of extreme urgency or in cases of public non-commercial use." On the current wording of section 4, prior negotiations with the patent owner could be required even where a national emergency or other extreme urgency is present, or if the use is public non-commercial use. ${ }^{38}$ However, state use cannot always entail noncommercial use, such as where the use is for economic development or by third parties. Therefore, the state use provisions require careful redrafting to distinguish between state use in situations of extreme urgency, public noncommercial use, and regular situations where prior negotiations would still be a requirement. Australia previously held the position that all Crown use entailed non-commercial use, but has backtracked by explicitly updating their Crown use provisions (by way of a 2020 amendment) ${ }^{39}$ to require prior negotiations except in emergency situations. The United States of America's utilisation of Government use provisions ${ }^{40}$ in neither requiring prior negotiations under any circumstances nor informing a patent rights

legislative and other measures to realise the right to have access to health care services progressively. This includes the utilization of TRIPS flexibilities such as Article 31(b), in full accordance with South African law."

See Art 31(b) of the World Trade Organization Agreement on Trade-Related Aspects of Intellectual Property Rights (1994) (TRIPS). South Africa became a member of the World Trade Organization on 1 January 1995. See Park, Prabhala and Berger Using Law to Accelerate Treatment Access 59-61 (para 2.6.1) on the application of Art 31 (b) to s 4 of the Patents Act, particularly the interpretation that any government use without any restrictions would fall under the "public non-commercial use" exception to prior negotiations requirement.

See Park, Prabhala and Berger Using Law to Accelerate Treatment Access 64 (para 2.6.2.3), contrasting the South African position with that of the United States of America (in terms of the Tucker Act 28 USC §1498), and the United Kingdom (in terms of s 55(1) of the Patents Act, 1977), which allow much broader powers of government use.

The Intellectual Property Laws Amendment (Productivity Commission Response Part 2 and Other Measures) Act 9 of 2020 was enacted into legislation on 27 February 2020, and the Intellectual Property Laws Amendment (Productivity Commission Response Part 2 and Other Measures) Regulations, 2020 came into force on 2 April 2020. This article discusses it in more detail under s 4 "Crown use provisions in the Australian Patents Act 83 of 1990" below.

The United States' government use provisions applicable to patents are found in the Tucker Act 28 USC $\$ 1498$ and not in the Patents Act 35 USC. This section provides simply that whenever a patent is used or manufactured by the Government, the owner is entitled to reasonable and entire compensation. It neither stipulates the purposes for which the government may use a patent, nor requires the patent holder to be informed of such use. 
holder of the use is not compliant with TRIPS requirements ${ }^{41}$ and needs careful consideration. 42

The Intellectual Property Policy Phase $12018^{43}$ does not explicitly mention the commitment to utilising Article 31 of TRIPS for the progressive realisation of access to healthcare, but it does mention the government use of patents in the field of pharmaceuticals. The state use provisions can certainly further access to healthcare, since it allows the state use of patents for a public purpose, and that would include, at the very least, the human rights that the state needs to protect and promote (like access to healthcare).

\subsection{Preliminary conclusions on the South African state use provisions}

Although legislators updated South African compulsory licence provisions ${ }^{44}$ in 1997 to include the guidelines from Article 31 of TRIPS, ${ }^{45}$ this was not done in relation to the state use provisions. An update is urgently required if the South African state wishes to rely effectively on the state use provisions in the public interest or for a public use in compliance with the Constitution and TRIPS. This is of even greater importance in the light of the state of national disaster caused by the worldwide COVID-19 outbreak. It is of paramount importance and plainly in the public interest to get timely and affordable access to patented articles such as personal protective equipment, vaccines, other pharmaceuticals, ventilators, and testing apparatus relating to the pandemic. As such, section 4 of the Patents Act must be amended urgently and speedily, in order to explicitly allow for the waiver of the prior negotiations requirement when the state needs to utilise a patent for a public purpose related to a state of national emergency or other situations of extreme urgency. The amended section 4 also needs to cater for other non-emergency public uses of patents (both public noncommercial use and commercial use), and as such must be drafted in a nuanced way. The foreign jurisdictions considered below provide some guidance, but ultimately the South African position may require a different approach to utilise fully TRIPS' Article 31 flexibilities to promote the country's developmental needs.

$41 \quad$ See Rushing 2012 Vand J Transnat'l L 879-916.

42 The position of other jurisdictions is considered in more detail in the sections below.

43 Intellectual Property Policy of the Republic of South Africa Phase 12018 28-29 (para

7.1.9.1 Government use).

$44 \quad$ Sections 55 and 56 of the Patents Act 57 of 1978.

$45 \quad$ The Intellectual Property Laws Amendment Act 38 of 1997. 


\section{Crown use provisions in the United Kingdom Patents Act 1977}

\subsection{Historical background of the United Kingdom Crown use provisions}

As early as the Venetian Statute of 1474, legislation provided no patent protection detrimental to governing authorities' interests. ${ }^{46}$ The English Statute of Monopolies of 1623 was introduced into early South African patent law by virtue of the British occupation. ${ }^{47}$ Hence, the state use provisions originated with the Crown use provisions. This shared history may shed some light on the nature and function of the provisions. During the last quarter of the seventeenth century, patent grants served the Crown's business and commerce, and they were awarded mostly in the field of currency and military supply. The Crown and military authorities could conduct security-related affairs without respect for the patent rights granted. ${ }^{48}$ Historically, Letters Patent did not bind the Crown. This changed only in 1883, when the effect of patents came to apply also to the Crown, but subject to the Crown use provisions. National security ordinarily justifies these provisions, and the notion that the prospect of compensation for Crown use as an incentive to continue to invent equates with full patent monopoly rights. ${ }^{49}$

\subsection{The United Kingdom Crown use provisions}

Section 55 of the Patents Act 1977 (hereafter the United Kingdom Patents Act) details the use of patented inventions in services of the Crown. Sections 56 to 59 provide further guidance on the interpretation of these provisions, remuneration for use, and special provisions for Crown use during emergencies. These provisions entail special compulsory licences benefiting the Crown, ${ }^{50}$ or an exemption from patentees' exclusive rights. ${ }^{51}$

Various questions emerge in the context of Crown use, including who may perform the acts in service of the Crown, which acts fall within the

May and Sell Intellectual Property Rights 85.

Van der Merwe "Law of Patents" 360.

May and Sell Intellectual Property Rights 85.

Cornish, Llewelyn and Aplin Intellectual Property 323-324. These provisions may feed into the instrumentalist logic as defined by John Dewey.

50 Bently et al. Intellectual Property Law 688; Pfizer Corporation v Ministry of Health [1965] AC 512.

$51 \quad$ Cornish, Llewelyn and Aplin Intellectual Property 323-326. 
provisions, and what remuneration is due..$^{52}$ Anyone authorised (in writing) to act on the Crown's behalf is included, and authorisation can be given after Crown use has already commenced. The provisions exclude selling and offering for sale, but include making, using and importing. The provisions do not require the state or state-authorised entity to attempt negotiations with the patent owner before invoking the Crown use provisions, and an entity may obtain authorisation (which provides the Crown use defence) after infringing acts have already taken place. ${ }^{53}$ This does not comply with the TRIPS requirement of prior negotiations (unless all Crown use entails noncommercial use).

Section 56(2) of the United Kingdom Patents Act includes within the ambit of the services of the Crown

(a) the supply of anything for foreign defence purposes; (b) the production or supply of specified drugs and medicines; and (c) such purposes relating to the production or use of atomic energy. ${ }^{54}$

However, these are merely examples and do not constitute an exhaustive list. ${ }^{55}$ In the South African context, state use involving the supply of pharmaceuticals is of particular importance, and a reasonable interpretation of section 4 of the South African Patents Act would certainly include this under the definition of public use. It would not be necessary to amend section 4 to include it explicitly in order to use it for that purpose.

Section 57(5) of the United Kingdom Patents Act permits the High Court to determine the appropriate compensation payable to the patentee or exclusive licensee for the loss of manufacturing or other profit, in the event of no agreement between the patent holder and the government department concerned. The court makes this determination after the commencement of Crown use. ${ }^{56}$ Courts follow an approach similar to that used in compulsory licence proceedings: attempting to determine the terms to which a willing licensor and licensee would have agreed. Additionally, a court can award compensation for lost contracts. Courts may add reasonable manufacturing profit as usually included in government tenders over and above any notional licence fee for use. ${ }^{57}$ In line with Article 31 of TRIPS, courts must

\footnotetext{
52 Cornish, Llewelyn and Aplin Intellectual Property 324-325.

53 Dory $v$ Sheffield Health Authority [1991] FSR 221.

54 Section 56(2) of the United Kingdom Patents Act, 1977.

55 IPCom GMBH \& Co KG v Vodafone Group PIC [2020] EWHC 132 (Pat) paras [188][189].

56 Cornish, Llewelyn and Aplin Intellectual Property 324-325; Bently et al. Intellectual Property Law 689, 696.

57 Patchett's Patent [1967] RPC 237; Bently et al. Intellectual Property Law 696.
} 
factor in the economic value of the Crown use. Section 57A(3) also mandates that the "profit which would have been made on such a contract" must be considered in determining the compensation for loss. While this determination of compensation for Crown use is useful to determine the market value of state use, South Africa employs market value as only one of the factors considered in determining compensation for expropriation, so the result may yet be very different in the light of section 25 of the Constitution.

\subsection{Some clarity from a recent United Kingdom case on Crown use}

IPCom GMBH \& Co KG v Vodafone Group PIC ${ }^{58}$ deliberated on the Crown use defence, deciding that neither subsection 56(2) nor section 59 of the United Kingdom Patents Act provides exclusive lists, but rather embodies examples of the kind of services that could be included. ${ }^{59}$ It also decided that an explicit authorisation to fulfil a specific mandate on behalf of the Crown would implicitly include authorisation in terms of the Crown use provisions to infringe a specific patent. "Vodafone were authorised in writing by a government department to provide priority access to their network for emergency responders" but confusion remained over whether the express authorisation must relate to a particular patent. Requiring this would place an extra burden in addition to the requirement in section 55(7)(a) to notify a patent owner of any Crown use "as soon as practicable" after the commencement of the use, as it would be impractical to identify all possible patents that might be implicated. ${ }^{60}$ In other words, identifying the relevant act but not the particular patent in the written authorisation is sufficient to authorise Crown use and subsequently to provide the defence to infringement. The court mentioned Article 31 of TRIPS and the prior negotiations requirement, but deemed them irrelevant to the facts. ${ }^{61}$

$58 \quad I P C o m$ GMBH \& Co KG v Vodafone Group PIC [2020] EWHC 132 (Pat) paras [184][213], referring to MMI Research $v$ Cellxion [2009] EWHC 1533 (Pat) and Pfizer Corporation $v$ Ministry of Health [1965] AC 512: Crown use must have been authorised in writing; Henry Brothers (Magherafelt) $v$ Ministry of Defence [1999] RPC 442, CA: The concept of Crown benefit includes the use of an invention relating to prefabricated blast-resistant building structures in a police station. IPCom GMBH \& Co KG v Vodafone Group PIc [2020] EWHC 132 (Pat) paras [188][189].

60 IPCom GMBH \& Co KG v Vodafone Group PIc [2020] EWHC 132 (Pat) paras [191][194].

61 IPCom GMBH \& Co KG v Vodafone Group PIC [2020] EWHC 132 (Pat) paras [195][206]. 


\section{Crown use provisions in the Australian Patents Act 83 of 1990}

\subsection{Historical background of the Australian Crown use provisions}

A brief history of the Australian Crown use provisions highlights Australia and South Africa's shared historical relationship with United Kingdom law, in that both countries' intellectual property legislation evolved from the Patents, Designs and Trade Marks Act, 1883 (IMP). In this regard the United Kingdom Crown use provisions were incorporated into section 27(2). ${ }^{62}$ As such, the purpose and justifications of the Crown use provisions in all three jurisdictions are comparable.

In Australian law the ambit and purpose of the Crown use provisions and related powers entail exploiting or acquiring patents without the express authority of the patentee but subject to remuneration for use (or compensation for acquisition), and to balance the grant of exclusive patent rights with the Australian public's needs. ${ }^{63}$ The Australian Crown use provisions have undergone a very recent overhaul, and South Africa's state use provisions might benefit from this process.

\subsection{The Australian Crown use provisions}

Section 163 of the Patents Act 83 of 1990 (hereafter the Australian Patents Act) allows the Commonwealth, a state, or an authorised person ${ }^{64}$ to exploit a patent for the provision of services to the Commonwealth in Australia if the invention is necessary for the provision of such services. This exploitation does not entail an infringement of the rights in the invention or the patent. The Crown use provisions ensure "immediate access to inventions for the benefit of the services of the respective governments", and provide a "statutory shield against patent infringement actions."65 However, the new section 163 now qualifies that infringement takes place

Bodkin Patent Law in Australia 799; Feathers v The Queen [1865] 6 B\&S 257.

Advisory Council on Intellectual Property 2005 https://www.ipaustralia.gov.au/sites/ default/files/acip_final_report_review_of_crown_use_provisions_archived.pdf 1; Davison, Monotti and Wiseman Australian Intellectual Property Law 575. See s 171 (Crown acquisitions), s 172 (assignments to the Crown) and ss 163-170 (Crown use).

This might include contractors as well as instruments of the Crown: O'Sullivan and Rolls Practical Guide to Australian Patent Law 316.

Davison, Monotti and Wiseman Australian Intellectual Property Law 574-575; Bodkin Patent Law in Australia 799. 
during non-compliance with terms agreed on or determined in terms of section $165 .^{66}$

The Crown use rights limit a patentee's exploitation rights. Before the 2020 amendments, the Crown could simply pay compensation for use as agreed or determined by the court, without prior authorisation negotiations with the patentee. ${ }^{67}$ The 2020 amendments ${ }^{68}$ added the requirement of prior negotiations with the patent rights holder before the commencement of any use, bar in instances of emergency (in which case the rights holder is still entitled to written notice of the order for Crown use and the terms and conditions). The provisions now explicitly require that the relevant authority must have "tried for a reasonable period, but without success, to obtain from the applicant and the nominated person, or the patentee, an authorisation to exploit the invention on reasonable terms". ${ }^{69}$ The relevant Minister must have given written approval before the commencement of any exploitation, and the rights holder must receive notice of approval and written reasons for the approval at least 14 days before the initiation of the exploitation. ${ }^{70}$

Crown use exemptions facilitate the exploitation of a patented invention for the proper provision of services of the Commonwealth (the Australian government) or a state (a particular state in Australia). However, it was unclear exactly which services were included under these provisions; particularly whether something like the provision of "railway transport or public hospital services, or the provision of pharmaceutical drugs in public hospitals" would be included. ${ }^{71}$ Crown use provisions could feature where gene patents are required in the provision of public healthcare, where public research requires biotechnology patents, and healthcare services and products could be explicitly included under the Crown use concept of services. ${ }^{72}$ South Africa could advance healthcare interests similarly, especially considering the Intellectual Property Policy and the state's

66 Section 163(2) of the Patents Act 83 of 1990, as amended in 2020.

67 Van Caenegem Intellectual Property Law and Innovation 107; O'Sullivan and Rolls Practical Guide to Australian Patent Law 315-319: Crown use provisions entail a "significant qualification on the monopoly rights of a patentee" permitting use for the provision of public services and in the public interest, citing Banks British Patent System (Banks Committee Report) 121. Introduced by the Intellectual Property Laws Amendment (Productivity Commission Response Part 2 and Other Measures) Act 9 of 2020.

Section 163(3) of the Patents Act 83 of 1990, as amended in 2020.

Van Caenegem Intellectual Property Law in Australia 112-113. Nielsen and Nicol 2008 Fed L Rev 339 agree that the use of Crown use provisions for humanitarian purposes needs greater exploration.

72 Australian Law Reform Commission Genes and Ingenuity ch 26; Nielsen and Nicol 2008 Fed L Rev 360. 
obligations towards socioeconomic rights such as healthcare, and the national disaster caused by the COVID-19 pandemic.

Section 160A(4) was added to the Australian Patents Act to clarify that Crown use services are those that are primarily provided or funded by either the Commonwealth or the relevant State or Territory (or in combination). This approach may inform South African law, as it could imply the inclusion of services that the South African State and provinces primarily provide and/or fund: municipal, healthcare and educational services, among others.

There are two diverging general justifications for Crown use provisions in Australian law. First, the government grants the patent monopoly (a privilege) and this should not impede the fulfilment of its functions, since the government should still have timeous access to new technology for service provision. Secondly, use for public purposes and the concomitant benefits outweigh the decrease in the innovation incentive. Any concerns that lowered incentives may completely prevent invention are countered by adequate Crown use remuneration. Also, prior negotiations are now strictly required, except in instances of national emergency.

Vaguely phrased Crown use provisions cover a wide array of situations, and are used rarely and carefully. ${ }^{73}$ In Stack $v$ Brisbane City Council ${ }^{74}$ the Federal Court of Australia considered the Crown use of a patent over water meters by the Brisbane City Council to levy charges for the supply to users based on consumption. The 2020 amendments address some of the concerns that prevent utilisation of the Crown use provisions so that they can address market failure more efficiently.

It is generally assumed that though the provisions are seldom used, "the threat of utilising the Crown use provisions [assists] Crown bodies to compel

73 Nielsen and Nicol 2008 Fed $L$ Rev 336: Despite arguments that the mere existence of the provisions promotes voluntary licensing activities, this may not be enough to "justify the ongoing presence of unused and unusable legislative provisions." In addition to the Crown use provisions (and like s 80 of the South African Patents Act), s 173 of the Australian Patents Act permits the restriction or prohibition of the publication of information from a patent application (even an international application) in the interest of the defence of the Commonwealth. Thus, access to micro-organism deposits may be restricted. See O'Sullivan and Rolls Practical Guide to Australian Patent Law 318.

$74 \quad$ Stack v Brisbane City Council (1995) 32 IPR 69; Van Caenegem 1995 QLSJ 55; General Steel Industries Inc v Commissioner of Railways (NSW) (1964) 112 CLR 125: An invention for the construction of rail carriages falls under these provisions; Bowrey, Handler and Nicol Australian Intellectual Property 523-525. 
parties to enter into licensing agreements voluntarily."75 Concerns that the threat of invoking the Crown use provisions might put patent owners in an unequal bargaining position and lower confidence in the Australian patent system ${ }^{76}$ have little legitimacy, since Crown use attracts remuneration, which balances economic incentives and public interests. Remuneration for Crown use is determined similarly to remuneration for compulsory licences, so any perceived unfairness would probably be similar in both instances.

\subsection{The impact of Article 31 of TRIPS on the Australian Crown use provisions}

Another issue ${ }^{77}$ was the TRIPS Agreement's ${ }^{78}$ Article 31 requirement of prior negotiations with the patent holder. This entails that the state must first attempt to obtain a voluntary licence from the patent holder, and states can waive these obligations only in urgent situations such as national emergencies ${ }^{79}$ or in circumstances of public non-commercial use. ${ }^{80}$ While the previous section 163(1) required notification to a patent owner, authorisation for Crown use was automatic (no application to the Federal Court was necessary), and no prior negotiation for a voluntary licence was required. ${ }^{81}$ An update to Australian patent law included the prior negotiations requirement for compulsory licence provisions in 1994, ${ }^{82}$ but not in relation to the Crown use provisions until 2020, as explained. The reason previously given for waiving the prior negotiations requirement was

$75 \quad$ Nielsen and Nicol 2008 Fed L Rev 361; Advisory Council on Intellectual Property 2005

https://www.ipaustralia.gov.au/sites/default/files/acip_final_report_review_of_crown _use_provisions_archived.pdf 8: Although there are few cases on Crown use, abuse of the provisions may occur without formal invocation. Advisory Council on Intellectual Property 2005 https://www.ipaustralia.gov.au/sites/ default/files/acip_final_report_review_of_crown_use_provisions_archived.pdf 1 . Advisory Council on Intellectual Property 2005 https://www.ipaustralia.gov.au/sites/ default/files/acip_final_report_review_of_crown_use_provisions_archived.pdf 1 . Agreement on Trade-Related Aspects of Intellectual Property Rights (1994). The WTO's Doha Declaration on the TRIPS Agreement and Public Health (2001) 5(a) explains that Member states can each determine the meaning of "national emergency" and "extreme urgency", adding that a public health crisis is included. See De Carvalho TRIPS Regime 31.33: a national emergency is an example of extreme urgency and the urgency must be extreme before the exception from prior licensing negotiations may be implemented. The economic value of the government use must be considered when determining the terms of use (including compensation). Wiseman Australian Intellectual Property Law 574-580; Nielsen et al. 2014 AIPJ 7492.

Sen and Nicol 2008 Fed L Rev 339 Patents (World Trade Organisation Amendments) Act, 1994 (Cth). 
that all Crown use entailed public non-commercial use. ${ }^{83}$ Although the Australian Crown use provisions are now compliant with Article 31 of TRIPS, the previous approach and its developments remain important, since South African policy makers wish to interpret and develop the state use provisions under the public non-commercial use exception. As long as the amendment distinguishes between instances of national emergency, public noncommercial use, and instances where state use does not fall under the public non-commercial exception, this will be a desirable development.

The scope of all Crown use/state use/government use provisions is limited by international obligations, particularly in sections 30 and 31 of TRIPS, which probably prompted Australia's 2020 amendments. ${ }^{84}$ The minimum standards of protection required from TRIPS members bind Australia and South Africa equally. ${ }^{85}$ South African lawmakers should consider this aspect fully, to amend the state use provisions in the South African Patents Act in a nuanced way in line with the goals and suggestions in the Intellectual Property Policy. Article 31 of TRIPS, which is applicable to Crown use provisions as well as compulsory licences (because it stipulates "use by the government or third parties authorized by the government"), explicitly stipulates:

[U]se may only be permitted if, prior to such use, the proposed user has made efforts to obtain authorization from the right holder on reasonable commercial terms and conditions and that such efforts have not been successful within a reasonable period of time. This requirement may be waived by a Member in the case of a national emergency or other circumstances of extreme urgency or in cases of public non-commercial use [emphasis supplied] ${ }^{86}$

Australia enacted the Intellectual Property Laws Amendment (Productivity Commission Response Part 2 and Other Measures) Act 2020 into

83 Nielsen and Nicol 2008 Fed L Rev 343: even before the introduction of Art 31 bis on pharmaceutical products, the provision was "cumbersome, inefficient and unworkable". Also see Advisory Council on Intellectual Property 2005 https://www.ipaustralia.gov.au/sites/default/files/acip_final_report_review_of_crown use_provisions_archived.pdf 16, referring to Review of Legislation in the Fields of Patents, Layout-Designs (Topographies) of Integrated Circuits, Protection of Undisclosed Information and Control of Anti-competitive Practices in Contractual Licences, Response to the Council for Trade-Related Aspects of Intellectual Property Rights, World Trade Organisation, Geneva (1997). Nielsen and Nicol 2008 Fed L Rev 340: while Art 7 of TRIPS purports to encourage finding a balance between the needs of intellectual property rights owners and users of intellectual property objects, member states have found it difficult to utilise TRIPS flexibilities. 
legislation on 27 February 2020, ${ }^{87}$ and the Intellectual Property Laws Amendment (Productivity Commission Response Part 2 and Other Measures) Regulations 2020 came into force on 2 April 2020. They amend the Crown use provisions. This amendment explicitly bringing the Australian Crown use provisions in line with the TRIPS obligations is very timely in the light of the COVID-19 pandemic. The Australian Minister of Industry is already considering implementing the Crown use provisions in order to stop patent rights from preventing Australia from responding to the health emergency adequately. ${ }^{88}$ South Africa should also be ready and willing to amend and use the state use provisions encapsulated in section 4 of the South African Patents Act in order to further the public purpose of facilitating access to healthcare in response to the COVID-19 pandemic and its concomitant fallouts, but also for broader purposes.

This 2020 Australian amendment implements the prior negotiations requirement explicitly, ${ }^{89}$ and overtly provides for its waiver only in emergencies. ${ }^{90}$ Even this exception still states that infringement would not be excused if an agreement has been reached but the terms are not complied with. The relevant Minister must still approve any exploitation in writing, prior to the commencement of such exploitation. It also still requires that the rights holder must be informed of the approval of the exploitation with reasons, although the " 14 days before commencement" rule is relaxed to "as soon as practicable after" the Minister's approval.

Previously there were questions regarding the meaning of "authorised"91 (regarding who may invoke the Crown use provisions). ${ }^{92}$ The 2020 amendment now explicitly refers to the Relevant Minister. In South African

87 IP Australia $2020 \mathrm{https} / / /$ www.ipaustralia.gov.au/about-us/public-consultations/ intellectual-property-laws-amendment-productivity-commission-response on Schedules 1 and 2: the Act improves transparency and accountability for Crown use, delimits when it is applicable, introduces Ministerial oversight, assists courts with the remuneration standard to determine adequate compensation for the rights holder, and improves the balance between the rights holder and the community's access to technology (via Government).

Hay et al. 2020 https://corrs.com.au/insights/covid-19-when-do-private-patentrights-give-way-to-the-public-interest: Crown use provisions are particularly apt in responding to COVID-19 because they can assist in meeting the demand for medical equipment, pharmaceuticals, personal protective equipment, and a vaccine once available, and promote local manufacturing. Section 163(3) of the Patents Act 83 of 1990.

Section 163A of the Patents Act 83 of 1990.

Advisory Council on Intellectual Property 2005 https://www.ipaustralia.gov.au/sites/ default/files/acip_final_report_review_of_crown_use_provisions_archived.pdf 1 . shed light on the meaning of public authority and its application to the meaning of authority of the Commonwealth or of a State. 
law, the state power provisions specify the relevant authority as the Minister of Economic Affairs and Technology ${ }^{93}$ for section 4 use and section 78 acquisitions; the Minister of Defence for section 79 assignments, and any Minister of State for section 80 secrecy issues.

\subsection{Remuneration for Crown use}

On remuneration and terms for exploitation, section 165 of the Australian Patents Act states that the authorised party invoking the Crown use provisions and the holder of the patent rights may agree upon them, but failing that, a prescribed court may make such determination upon application by either party. ${ }^{94}$ The 2020 amendment updated section 165, notably adding that absent agreement, the terms for exploitation and remuneration must be determined by the prescribed court, determining just and reasonable remuneration, "regarding the economic value of the exploitation of the invention and any other matter the court considers relevant." The South African provisions state (in much less detail) that a court can determine the terms, which would include remuneration. Nonetheless, a court must consider constitutional principles and the guidelines in the property clause ${ }^{95}$ in determining adequate remuneration, especially since section 4 of the South African Patents Act references public purposes, closely matching the wording of section 25 of the Constitution. If adequate remuneration (determined as guided by constitutional principles) is provided to the patent owner by the State, it would certainly be much harder to pinpoint any (arbitrary) deprivation or uncompensated expropriation during any potential subsequent constitutional property review following a determination made by a High Court judge sitting as the commissioner of patents.

Australian law suggests two standards (used in compulsory licence proceedings) that a court might utilise to determine remuneration for a patent holder whose patent is subject to a compulsory licence: remuneration based on a standard that adequately compensates the holder, or remuneration based on a reasonable royalty (generally the lower rate

\footnotetext{
93 Now the Minister of Trade and Industry.

94 Bodkin Patent Law in Australia 805-807 cites the English Court of Appeal case of Patchett's Patent [1967] FSR 249 at 256 per Willmer LJ at 263 per Diplock LJ and at 268 per Winn LJ to argue that compensation for Crown use should be determined "as if the 'Crown user' were a licensee under the patent, and appropriate terms are those that would be agreed between a willing licensee and a willing licensor, both bargaining on equal terms" and taking into account the extent of the use and considerations that would be relevant in the case of a compulsory licence. Section 25(3) of the Constitution.
} 
between the two). Most often, compulsory licensing proceedings use a reasonable royalty rate, generally interpreted as that amount on which a willing licensor and willing licensee would agree, factoring in the monopoly profit and variables like risk and delays in return. ${ }^{96}$

\subsection{Patent acquisition by the Australian Commonwealth}

The Australian Patents Act provides for the acquisition of inventions or patents by the Commonwealth, stipulating that the patent holder must receive compensation, which is to be determined by a court in the absence of agreement. ${ }^{97}$ Section 51 (xxxi) of the Commonwealth of Australia Constitution Act, 1900 (UK) (the property clause) is explicitly mentioned in academic discussions of state acquisitions of patents, ${ }^{98}$ confirming that Crown utilisation provisions provide for a compulsory acquisition (or use against the wishes of a patent owner) where negotiations have failed. For a compulsory acquisition to comply with section 51 (xxxi) there must be compensation on just terms. ${ }^{99}$ While "the power to enact laws with respect to the acquisition of property on just terms under section 51 (xxi)" is an alternative power on which the Commonwealth Government may rely when it is necessary to use intellectual property without the owner's consent, more legislation would then be needed replacing the Crown provisions. ${ }^{100}$ This transposes to South African law. In place of the state power provisions that authorise the utilisation, acquisition and assignment of patents by the South African Government, the process would probably have to take place via the Expropriation Act 63 of 1975, which grants the power to expropriate to a variety of governmental institutions. ${ }^{101}$

\section{Use of patents by Government in the Canadian Patent Act RSC 1985 c P4}

\subsection{Canadian Crown use of patents}

The Crown could freely use patents at common law, but it was limited in the sense that the immunity extended only to government employees or agents

Nielsen and Nicol 2008 Fed L Rev 354.

Section 171(4) of the Patents Act 83 of 1990; Bodkin Patent Law in Australia 807.

Van Caenegem Intellectual Property Law in Australia 113.

O'Sullivan and Rolls Practical Guide to Australian Patent Law 318.

Advisory Council on Intellectual Property 2005 https://www.ipaustralia.gov.au/ sites/default/files/acip_final_report_review_of_crown_use_provisions_archived.pdf 9-10.

101 Section 173(3) of the Expropriation Act 63 of 1975. See O'Sullivan and Rolls Practical Guide to Australian Patent Law 318. 
and not to contractors, and voluntary payments accompanied patent use so that inventions potentially assisting the state in military activities remained incentivised. Until 1994 the federal government simply paid reasonable compensation for the use of a patent, as determined by the Commissioner of Patents where the parties could not agree on suitable remuneration. ${ }^{102}$

Since 1994, after TRIPS, the Canadian federal and provincial governments have to negotiate with patent holders before using their patents. Only where the negotiations fail can they apply to the Commissioner of Patents for a non-exclusive right permitting the domestic use of the patent. ${ }^{103}$ National emergency, other extreme urgency or public non-commercial use may justify waiving the requirement of prior negotiations, but not the Commissioner's prior consent. ${ }^{104}$ Public non-commercial use includes purposes like building a bridge where tolls merely recoup building costs, providing public health care, acquiring medicine, conducting public university research, and in defence of the country. ${ }^{105}$

Section 19(1) of the Patent Act RSC 1985 c P4 (hereafter the Canadian Patent Act) provides that "the Commissioner may, on application by the Government of Canada or the government of a province, authorize the use of a patented invention by that government". However, section 19(4) on payment of remuneration mentions nothing of agreement between the authorised user and the holder of the patent rights. It states only that "the authorized user shall pay to the patentee such amount as the Commissioner considers to be adequate remuneration in the circumstances, taking into account the economic value of the authorization." This remuneration probably entails what "a willing licensor and non-exclusive licensee would notionally have agreed on for Canadian rights as equal bargaining parties."106 The Canadian Crown use provisions meet the TRIPS requirement of prior negotiations with the patentee. The applicant must establish that "it has made efforts to obtain from the patentee on reasonable commercial terms and conditions the authority to use the patented invention; and its efforts have not been successful within a reasonable

\footnotetext{
102 Vaver Intellectual Property Law 413-414; MacDonald v Canada (1906) 10 Ex CR 338; Dixon v London Small Arms Co Ltd (1876) 1 App Cas 632 (HL) 647.

103 Section 19.1(1)(a) and (b) of the Patent Act RSC 1985 c P4.

104 Section 19.1(2) of the Patent Act RSC 1985 c P4.

105 Vaver Intellectual Property Law 414; Reichman and Hasenzahl Non-voluntary Licensing of Patented Inventions: Canadian Experience 45-50; Reichman and Hasenzahl Non-voluntary Licensing of Patented Inventions: Historical Perspective 19-22.

$106 \quad$ Vaver Intellectual Property Law 414.
} 
period" unless there is a national emergency, a case of extreme urgency or public non-commercial use.

Similar to the provisions in South African, United Kingdom and Australian patent legislation, Canadian legislation also provides for the government acquisition of patents, subject to compensation (section 20 of the Canadian Patent Act).

\subsection{The COVID-19 Emergency Response Act SC 2020 c 5}

Canada assented to the COVID-19 Emergency Response Act SC 2020 c 5 on 23 March 2020. It makes a broad range of temporary changes to existing legislation in response to the COVID-19 emergency. Notably Part 12 of this Act amends the Canadian Patent Act by adding section 19.4(1)-(9), which contains a number of clarifications of the government use of patents during a public health emergency. Subsection 19.4(9) limits the period of use of this emergency legislation to 30 September 2020. Subsection 19.4(1) states:

The Commissioner shall, on the application of the Minister of Health, authorize the Government of Canada and any person specified in the application to make, construct, use and sell a patented invention to the extent necessary to respond to the public health emergency described in the application. ${ }^{107}$

Notably, the amendment mandates that an application to the Minister of Health must mention the specific patent affected (subsection 19.4(2)(a) and "specify a person, if any, that is to be authorized to make, construct, use and sell the patented invention for the purposes of responding to the public health emergency" (subsection 19.4(2)(d)). Subsection 19.4(5) clarifies the remuneration payable under such emergency circumstances:

The Government of Canada and any person authorized under subsection (1) shall pay the patentee any amount that the Commissioner considers to be adequate remuneration in the circumstances, taking into account the economic value of the authorization and the extent to which they make, construct, use and sell the patented invention. ${ }^{108}$

Nothing in this emergency legislation is exceptional compared to the general crown use provisions in the Canadian Patent Act, in the sense that there was nothing in the general exception to prior negotiations under the existing section 19.1 that would prevent the Canadian Government from utilising a patent speedily in a national emergency (such as the COVID-19 epidemic). The emergency legislation seems rather to limit the government's powers

107 Section 19.4(1) of the COVID-19 Emergency Response Act SC 2020 c 5.

108 Section 19.4(5) of the COVID-19 Emergency Response Act SC 2020 c 5. 
and the scope of patent use in mandating that an application must specify the patent in issue and the authorised person, and limiting the exclusive rights of the patent holder that may be utilised by the government under these legislative measures.

However, South Africa may certainly follow suit in the sense of speedily updating the South African state power provisions for patents in response to the public health emergency caused by COVID-19.

\section{Conclusion}

This article highlights the most important aspects of state use provisions that need contemplation when reviewing South African patent law based on the Intellectual Property Policy Part 1 2018. The urgency of getting clarity on what is permitted under state use for public purposes has intensified in the light of the COVID-19 pandemic. The provisions also require an update explicitly detailing that negotiating with a patent holder prior to state use is unnecessary in instances of national emergency or other instances of extreme urgency. Section 4 of the South African Patents Act allows the Minister of Economic Affairs and Technology ${ }^{109}$ to use an invention for public purposes on terms as agreed with the patentee or as determined by the commissioner of patents, permitting the patentee to be heard before determination. The conditions determined must include adequate compensation, taking into account the current use and market value of the property, any state investment in creating the property, and the purpose of the use, in line with section 25(3) of the Constitution. The purpose of the state use may even mandate a higher level of compensation to incentivise the creation of inventions with public benefits.

The legislative amendment must clarify which exclusive patent rights are affected - will this entail making, using, exercising, disposing, offering to dispose of, or importing the invention? United Kingdom law excludes selling and offering for sale (unless ancillary or incidental to the other exclusive rights) from rights permitted for Crown use (encompassing the public noncommercial use exception), while Australian law includes selling under Crown use (section 167 of the Australian Patents Act). Each exclusive right has a different market value. Important considerations also include whether use is temporary as well as the portion of the monopoly period impacted on.

109 Now the Minister of Trade and Industry. 
Determining compensation only after use is practical, though this is separate from the prior negotiations issue.

The South African state use provisions should define public use in more detail, guided by the meaning as used in section 25 of the Constitution. Specifying use for foreign defence purposes, the production or supply of specified drugs and medicines, and the production or use of atomic energy as in United Kingdom law, as examples of possible public uses would be useful, but it must be an open list allowing the commissioner of patents to decide the scope as required. Section 4 does not indicate whether the Minister may authorise only government institutions or also private entities providing government services (via tenders), and it is likely that in South Africa it would have to include private entities.

The legislative amendment to section 4 must provide guidelines for determining adequate remuneration for the restrictions on patent use in favour of the state (exceptional and unequal burdens forced on specific patentees in favour of public interest). Determining what a willing licensor and licensee might have agreed on, mindful of the economic value of the patent utilisation by the state, is merely a departure point. All of the factors as specified in section 25(3) of the Constitution need consideration in determining adequate remuneration. United Kingdom law remunerates generously in order to adequately encourage innovation, while Australian law views the benefit of the public use as outweighing any lowered incentive to innovate. Australian law generally recommends remuneration somewhere between adequate remuneration and a reasonable royalty, with the latter being the lower of the two.

Article 31 of TRIPS permits the government use of patents only if efforts were made to obtain authorisation from the rights holder on reasonable commercial terms and conditions, and this must be done prior to any such use. Only in cases of national emergency, extreme urgency or for public non-commercial use (and there are questions as to the limits of the Crown use falling into the last category) may this requirement be waived. While the United Kingdom does not currently implement the prior negotiations requirement (based on public non-commercial use), the March 2020 amendments to section 163 of the Australian Patents Act in Australia have brought this jurisdiction in line with Article 31 of TRIPS. The amendment to section 4 of the South African Patents Act should explicitly distinguish between the three different situations of state use: First, state use during an emergency or a situation of extreme urgency, in which case no prior negotiations are required and the patent holder is simply notified as soon as 
possible. Secondly, state use for public non-commercial use where prior negotiations are not required, but selling or offering for sale is excluded from the permitted state uses. Finally, any other state use that does not fall in the prior two categories; in other words, where the use would be commercial, in which case prior negotiations would be required before the use commences. In all three cases remuneration would be due, but its extent would be determined at different stages according to the category of state use.

South Africa should urgently update the state use provisions in the Patents Act in order to indicate clearly that state use provisions may be used without prior negotiations in a national emergency or any other situation of extreme urgency, of which the pandemic caused by COVID-19 is one example. As noted, the issue of waiving the prior negotiations requirement for state use in the instance of public non-commercial use should be addressed very carefully, since there may definitely be instances of public use that would be non-commercial, but state use could also be allowed for commercial purposes and in that case prior negotiations would be required (in line with Article 31 of TRIPS).

While various questions remain, it is imperative that public use as permitted in section 4 of the South African Patents Act must be informed by public use as formulated in section 25 of the Constitution. What is permitted under state use should be determined not by the status of the persons actually rendering the services for public use, but by the nature of the services themselves. Explicit permission to render a state service should include the use of patents generally, in the interest of expediency. The open formulation in section 4 of the South African Patents Act may be adequate; leaving it to the designated authorities to decide on a case by case basis what would constitute public use, fair terms of exploitation, and just compensation. This is especially pertinent to South Africa, given its advanced human rights framework as provided by the Constitution.

The state of national disaster caused by the worldwide COVID-19 outbreak necessitates timely and affordable access to patented products or processes (personal protective equipment, vaccines, other pharmaceuticals, ventilators, and testing apparatus relating to the pandemic). This clearly constitutes a public purpose under section 4 of the Patents Act, falling under the TRIPS exception waiving prior negotiations for emergency/extremely urgent situations; but to avoid doubt the state use provisions must be updated in a way that is openly compatible with the Constitution and TRIPS. 


\section{Bibliography}

\section{Literature}

Alberts 2007 De Rebus

Alberts W "What is Intellectual Property?" 2007 De Rebus 45-46

Australian Law Reform Commission Genes and Ingenuity

Australian Law Reform Commission Genes and Ingenuity: Gene Patenting and Human Health (Australian Law Reform Commission Sydney 2004)

Banks British Patent System

Banks MAL The British Patent System: Report of the Committee to Examine the Patent System and Patent Law (HMSO London 1970)

Bently et al. Intellectual Property Law

Bently L et al. Intellectual Property Law $5^{\text {th }}$ ed (Oxford University Press Oxford 2018)

Biagio "Commercial Considerations"

Biagio D "Commercial Considerations for Transactions Involving Intellectual Property" in Dean O and Dyer A (eds) Dean and Dyer Introduction to Intellectual Property Law (Oxford University Press Cape Town 2014) 360389

Bodkin Patent Law in Australia

Bodkin C Patent Law in Australia $2^{\text {nd }}$ ed (Thomson Reuters Sydney 2014)

Bowrey, Handler and Nicol Australian Intellectual Property

Bowrey K, Handler M and Nicol D Australian Intellectual Property: Commentary, Law and Practice (Oxford University Press South Melbourne 2010)

Burrell Burrells South African Patent and Design Law

Burrell TD Burrells South African Patent and Design Law $4^{\text {th }}$ ed (LexisNexis Durban 2016)

Cornish, Llewelyn and Aplin Intellectual Property Cornish W, Llewelyn D and Aplin T Intellectual Property: Patents, Copyright, Trade Marks and Allied Rights $7^{\text {th }}$ ed (Sweet and Maxwell London 2010)

Davison, Monotti and Wiseman Australian Intellectual Property Law Davison MJ, Monotti AL and Wiseman L Australian Intellectual Property Law $3^{\text {rd }}$ ed (Cambridge University Press Port Melbourne 2016) 
De Carvalho TRIPS Regime

De Carvalho NP The TRIPS Regime of Patents and Test Data $5^{\text {th }}$ ed (Wolters Kluwer International Alphen aan den Rijn 2018)

Du Bois 2012 SA Merc LJ

Du Bois M "Intellectual Property as a Constitutional Property Right: The South African Approach" 2012 SA Merc LJ 177-193

Du Bois 2018 PELJ

Du Bois M "Justificatory Theories for Intellectual Property Viewed through the Constitutional Prism" 2018 PELJ 1-38

Du Bois 2018 SAIPLJ

Du Bois M "The Appropriate Scope of Property Rights in Patents" 2018 SAIPLJ 67-91

Du Bois and Shay "Regulation at the Edge of the Property Concept"

Du Bois M and Shay RM "Regulation at the Edge of the Property Concept: Judicial Treatment of Intangible Interests" in Muller G et al. (eds) Transformative Property Law: Festschrift in Honour of AJ van der Walt (Juta Cape Town 2018) 419-446

Gerntholtz Principles of South African Patent Law

Gerntholtz ROP Principles of South African Patent Law and a Comparative Reference to German Patent Law (Juta Cape Town 1971)

Grant "Patents"

Grant T "Patents" in Dean O and Dyer A (eds) Dean and Dyer Introduction to Intellectual Property Law (Oxford University Press Cape Town 2014) 237282

Hoops 2019 SALJ

Hoops B "Expropriation without Compensation: A Yawning Gap in the Justification of Expropriation?" 2019 SALJ 261-302

May and Sell Intellectual Property Rights

May C and Sell SK Intellectual Property Rights: A Critical History (Lynne Rienner London 2006)

Nielsen and Nicol 2008 Fed L Rev

Nielsen $J$ and Nicol D "Whither Patent Use without Authorisation in Australia?" 2008 Fed L Rev 333-364 
Nielsen et al. 2014 AIPJ

Nielsen $\mathrm{J}$ et al. "Another Missed Opportunity to Reform Compulsory Licenses and Crown Use in Australia" 2014 AIPJ 74-92

O'Sullivan and Rolls Practical Guide to Australian Patent Law

O'Sullivan C and Rolls C Practical Guide to Australian Patent Law (Lawbook Co Sydney 2003)

Park, Prabhala and Berger Using Law to Accelerate Treatment Access

Park C, Prabhala A and Berger J Using Law to Accelerate Treatment Access in South Africa: An Analysis of Patent, Competition and Medicines Law (UNDP New York 2013)

Ramsden Guide to Intellectual Property Law

Ramsden P A Guide to Intellectual Property Law (Juta Cape Town 2011)

Reichman and Hasenzahl Non-voluntary Licensing of Patented Inventions: Canadian Experience

Reichman $\mathrm{JH}$ and Hasenzahl C Non-voluntary Licensing of Patented Inventions: The Canadian Experience (UNCTAD-ISTSD Capacity Building Project on Intellectual Property Rights and Sustainable Development Geneva 2002)

Reichman and Hasenzahl Non-voluntary Licensing of Patented Inventions: Historical Perspective

Reichman $\mathrm{JH}$ and Hasenzahl C Non-voluntary Licensing of Patented Inventions: Historical Perspective, Legal Framework under TRIPS, and an Overview of the Practice in Canada and the United States of America (UNCTAD-ICTSD Capacity Building Project on Intellectual Property Rights and Sustainable Development Geneva 2003)

Rushing 2012 Vand J Transnat'l L

Rushing S "Plugging the Leak in $§ 1498$ : Coercing the United States into Notifying Patent Owners of Government Use" 2012 Vand J Transnat'I L 879916

Van Caenegem 1995 QLSJ

Van Caenegem W "Patent Law - A City Council is an 'Authority of a State"' 1995 QLSJ 555-559

Van Caenegem Intellectual Property Law and Innovation

Van Caenegem W Intellectual Property Law and Innovation (Cambridge University Press Melbourne 2007) 
Van Caenegem Intellectual Property Law in Australia

Van Caenegem W Intellectual Property Law in Australia (Wolters Kluwer Law and Business Austin 2010)

Van der Merwe "Law of Patents"

Van der Merwe A "The Law of Patents" in Van der Merwe A et al. Law of Intellectual Property in South Africa $2^{\text {nd }}$ ed (LexisNexis Durban 2016) 357427

Van der Walt Constitutional Property Law

Van der Walt AJ Constitutional Property Law $3^{\text {rd }}$ ed (Juta Cape Town 2011)

Van der Walt and Shay 2014 PELJ

Van der Walt AJ and Shay RM "Constitutional Analysis of Intellectual Property" 2014 PELJ 52-85

Vaver Intellectual Property Law

Vaver D Intellectual Property Law: Copyright, Patents, Trade-marks $2^{\text {nd }}$ ed (Irwin Law Toronto 2011)

Vawda 2019 SAIPLJ

Vawda YA "Analysing South Africa's Compulsory Licensing Jurisprudence: Is There Room for the Public Interest (PI) in Intellectual Property (IP)?" 2019 SAIPLJ 182-198

Vawda Compulsory Licensing Jurisprudence

Vawda YA Compulsory Licensing Jurisprudence in South Africa: Do we have our Priorities Right? (South Centre Geneva 2018)

Vawda and Shozi Eighteen Years after Doha

Vawda YA and Shozi B Eighteen Years after Doha: An Analysis of the Use of Public Health TRIPS Flexibilities in Africa (South Centre Geneva 2020)

Viljoen 2020 TSAR

Viljoen S "Expropriation without Compensation: Principled Decision-making instead of Arbitrariness in the Land Reform Context (Part 1)" 2020 TSAR $35-48$

\section{Case law}

\section{Australia}

General Steel Industries Inc v Commissioner of Railways (NSW) (1964) 112 CLR 125 
Stack v Brisbane City Council (1995) 32 IPR 69

\section{Canada}

MacDonald v Canada (1906) 10 Ex CR 338

\section{South Africa}

Ausplow (Pty) Ltd v Northpark Trading 3 (Pty) Ltd 20114 All SA 221 (SCA) Ensign-Bickford (South Africa) (Pty) Ltd v AECI Explosives and Chemicals Ltd 19991 SA 70 (SCA)

Letraset Ltd v Helios Ltd 19723 SA 245 (A)

Merck Sharp Dohme Group v Cipla Agrimed (Pty) Ltd 2015 BIP 101 (SCA)

Premier Hangers CC v Polyoak (Pty) Ltd 19971 SA 416 (A)

Roman Roller CC v Speedmark Holdings (Pty) Ltd 19961 SA 405 (SCA)

Schlumberger-Logelco Inc v Coflexip SA 20003 SA 861 (SCA)

\section{United Kingdom}

Dixon v London Small Arms Co Ltd (1876) 1 App Cas 632 (HL)

Dory v Sheffield Health Authority [1991] FSR 221

Feathers $v$ The Queen [1865] 6 B\&S 257

Henry Brothers (Magherafelt) v Ministry of Defence [1999] RPC 442

IPCom GMBH \& Co KG v Vodafone Group Plc [2020] EWHC 132 (Pat)

MMI Research v Cellxion [2009] EWHC 1533 (Pat)

Patchett's Patent [1967] FSR 249

Patchett's Patent [1967] RPC 237

Pfizer Corporation v Ministry of Health [1965] AC 512 


\section{Legislation}

\section{Australia}

Commonwealth of Australia Constitution Act, 1900 (UK)

Intellectual Property Laws Amendment (Productivity Commission Response Part 2 and Other Measures) Act 9 of 2020

Intellectual Property Laws Amendment (Productivity Commission Response Part 2 and Other Measures) Regulations, 2020

Patents Act 83 of 1990

Patents (World Trade Organisation Amendments) Act, 1994 (Cth)

\section{Canada}

COVID-19 Emergency Response Act SC 2020 c 5

Patent Act RSC 1985

\section{South Africa}

Constitution of the Republic of South Africa, 1996

Designs Act 195 of 1993

Expropriation Act 63 of 1975

Intellectual Property Laws Amendment Act 38 of 1997

Patents Act 37 of 1952

Patents Act 57 of 1978

\section{United Kingdom}

Patents Act, 1977

Patents, Designs and Trade Marks Act, 1883 (IMP)

Statute of Monopolies, 1623

Venetian Statute, 1474 


\section{United States of America}

Patents Act 35 USC

Tucker Act 28 USC

\section{Government publications}

\section{Australia}

Review of Legislation in the Fields of Patents, Layout-Designs (Topographies) of Integrated Circuits, Protection of Undisclosed Information and Control of Anti-competitive Practices in Contractual Licences, Response to the Council for Trade-Related Aspects of Intellectual Property Rights, World Trade Organisation, Geneva (1997)

\section{South Africa}

Draft Expropriation Bill, 2019 (GN 1409 in GG 42127 of 21 December 2018) Draft Intellectual Property Policy of the Republic of South Africa Phase 1 2017 (Gen N 636 in GG 41064 of 25 August 2017)

Intellectual Property Policy of the Republic of South Africa Phase 12018 (Gen N 518 in GG 41870 of 31 August 2018)

\section{International instruments}

Agreement on Trade-Related Aspects of Intellectual Property Rights (1994)

Doha Declaration on the TRIPS Agreement and Public Health (2001)

\section{Internet sources}

Alexander 2013 https://scholarship.law.cornell.edu/facpub/653/

Alexander GS 2013 Ownership and Obligations: The Human Flourishing Theory of Property https://scholarship.law.cornell.edu/facpub/653/ accessed 30 August 2020

Advisory Council on Intellectual Property 2005 https://www.ipaustralia.gov.au/sites/default/files/acip_final_report_review_ of_crown_use_provisions_archived.pdf

Australian Government: Advisory Council on Intellectual Property 2005 Review of Crown Use Provisions for Patents and Designs 
https://www.ipaustralia.gov.au/sites/default/files/acip_final_report_review_ of_crown_use_provisions_archived.pdf accessed 30 August 2020

Hay et al. 2020 https://corrs.com.au/insights/covid-19-when-do-privatepatent-rights-give-way-to-the-public-interest

Hay K et al. 2020 COVID-19: When Do Private Patent Rights Give Way to the Public Interest? https://corrs.com.au/insights/covid-19-when-do-privatepatent-rights-give-way-to-the-public-interest accessed 3 April 2020

IP Australia 2020 https://www.ipaustralia.gov.au/about-us/publicconsultations/intellectual-property-laws-amendment-productivitycommission-response

Australian Government: IP Australia 2020 Public Consultations: Intellectual Property Laws Amendment (Productivity Commission Response Part 2 and Other Measures) Act 2020 https://www.ipaustralia.gov.au/about-us/publicconsultations/intellectual-property-laws-amendment-productivitycommission-response accessed 12 March 2020

\section{List of Abbreviations}

AIPJ

Fed L Rev

PELJ

QLSJ

SALJ

SA Merc LJ

SAIPLJ

TRIPS

TSAR

Vand J Transnat'I L WTO
Australian Intellectual Property Journal

Federal Law Review

Potchefstroom Electronic Law Journal

Queensland Law Society Journal

South African Law Journal

South African Mercantile Law Journal

South African Intellectual Property Law Journal

Agreement on Trade-Related Aspects of Intellectual Property Rights

Tydskrif vir die Suid Afrikaanse Reg (Journal of South African Law)

Vanderbijlt Journal of Transnational Law World Trade Organization 